\title{
Meningkatan Hasil Belajar Writting Aviation Job Melalui Pemanfaatan Model Group Investigation Taruna Teknik Lisrik Bandara XI B ATKP Surabaya Tahun Ajaran 2016/2017
}

\author{
Fatmawati \\ Politeknik Penerbangan Surabaya \\ Jl. Jemur Andayani 1/73 Wonocolo Surabaya 60236 \\ Telp.(031)841087, Fax.(031)8490005
}

\begin{abstract}
ABSTRAK
Saat pembelajaran memahami Writting Aviation Job seringkali taruna melakukan kesalahan. Hal ini dikarenakan dosen tidak tepat dalam memilih metode pembelajaran. Permasalahan mendasardalam penelitian ini adalah sebagian besar taruna Teknik Listrik Bandara kelas XIB ATKP Surabaya Tahun Ajaran 2016/2017 kurang mampu dalam pembelajaran memahami Writting Aviation Job. Tujuan dari penelitian ini adalah untuk mengetahui apakah pemanfaatan metode group investigation dapat meningkatkan prestasi belajar Writting Aviation Job taruna Teknik Listrik Bandara kelas XIB ATKP Surabaya Tahun Ajaran 2016/2017. Penelitian ini menggunakan penelitian tindakan kelas ka rena penelitian tindakan kelas adalah merupakan penelitian yang lebih sesuai dengan tugas pokok dan fungsi dosen, meningkatkan kualitas pembelajaran, meningkatkan kualitas taruna, serta mencapai tujuan pembelajaran atau pendidikan. Dalam penelitian ini yang menjadi subyek penelitian adalah 24 taruna Teknik Listrik Bandara kelas XIB ATKP Surabaya Tahun Ajaran 2016/2017. Penelitian ini dilaksanakan pada bulan April 2017. Metode pengumpulan data pada penelitian ini adalah observasi, tes dan catatan lapangan. Teknik analisis data yang dipergunakan adalah reduksi data, penyajian data, penarikan simpulan, serta verifikasi refleksi.
\end{abstract}

Kata Kunci: Hasil Belajar, Writing, Group Investigation

\section{Pendahuluan}

Metode pembelajaran terus mengalami perubahan dari waktu ke waktu ke arah yang lebih baik yang diharapkan mampu mewujudkan tujuan pendidikan nasional. Oleh karena itu pembelajaran Bahasa Inggris perlu disampaikan dengan model pembelajaran dan strategi pendekatan yang inovatif dan kreatif, dimana salah satunya dengan metode group investigation yang diharapkan mampu mengembangkan keterampilan berpartisipasi dalam proses berbahasa melalui pengembangan ketrampilan interpersonal, intrapersonal, dan keterampilan akademis (Suprijono, 2016:71).

Banyak taruna menganggap bahwa pelajaran Bahasa Inggris merupakan mata pelajaran yang sulit dibandingkan dengan mata pelajaran yang lain. Kesulitan itu dapat dilihat dari kegagalan taruna dalam menguasai pelajaran Bahasa Inggris di sekolah. Berdasarkan kenyataan di ATKP Surabaya, dilaporkan bahwa kegagalan taruna dalam menguasai pelajaran Bahasa Inggris disebabkan kurang baiknya proses pembelajaran yang dilakukan oleh dosen. Pada kenyataannya dosen lebih banyak menggunakan model pembelajaran langsung, karena model ini paling mudah dilaksanakan. Selama ini taruna 
menerima begitu saja pengajaran Bahasa Inggris di sekolah, tanpa mempertanyakan mengapa atau untuk apa Bahasa Inggris harus diajarkan. Tidak jarang muncul keluhan bahwa Bahasa Inggris hanya membuat pusing taruna karena dianggap banyak bentuk dan kosakata yang membebani taruna. Kesulitan dalam belajar Bahasa Inggris yang membuat kekhawatiran pada hasil belajar taruna. Faktor lain yang ikut mempengaruhi adalah rasa bosan pada pelajaran bahasa, hal ini di dapat dari faktor penyampaian materi atau model pembelajaran yang monoton.

Melihat kondisi rendahnya hasil belajar tersebut upaya dilakukan penelitian salah satunya adalah dengan menerapkan model pembelajaran kooperatif tipe group investigation (Suprijono, 2016: 112). Berdasarkan uraian latar belakang di atas, rumusan masalah yang dapat dikemukakan peneliti adalah: Apakah penerapan pembelajaran kooperatif tipe group investigation dapat meningkatkan hasil belajar Writting Aviation Job di kelas TLB XIB ATKP Surabaya pada Tahun Ajaran 2016/2017?

Adapun tujuan yang ingin dicapai dalam penelitian ini adalah untuk mengetahui apakah penerapan pembelajaran kooperatif tipe group investigation dapat meningkatkan hasil belajar Writting Aviation Job di kelas XIB ATKP Surabaya Tahun Ajaran $2016 / 2017$.

\section{Kajian Teori}

Belajar adalah modifikasi atau memperteguh kelakuan melalui pengalaman. Belajar adalah penambahan pengetahuan. Ada pula yang menganggap belajar itu sebagai perubahan kelakuan berkat pengalaman dan latihan. Belajar merupakan komponen ilmu pendidikan yang berkenaan dengan tujuan dan bahan acuan interaksi, baik yang bersifat eksplisit maupun implicit (Sagala, 2008: 11).

Secara umum pembelajaran kooperatif dianggap lebih diarahkan oleh dosen yang menetapkan tugas dan pertanyaan-pertanyaan serta menyediakan bahan-bahan dan informasi yang dirancang untuk membantu peserta didik menyelesaikan masalah (Suprijono, 2015:74). Model pembelajaran kooperatif adalah salah satu model pembelajaran yang mendorong taruna untuk aktif bertukar pikiran dengan sesamanya dalam memahami suatu materi pembelajaran. Berdasarkan pandangan konstruktivistik, proses pembelajaran dengan model group investigation memberikan kesempatan seluasluasnya kepada taruna untuk terlibat secara langsung dan aktif dalam proses pembelajaran mulai dari perencanaan sampai cara mempelajari suatu topik melalui investigasi. Democratic teaching adalah proses pembelajaran yang dilandasi oleh nilai- 
nilai demokrasi, yaitu penghargaan terhadap kemampuan, menjunjung keadilan, menerapkan persamaan kesempatan dan memperhatikan keberagaman peserta didik (Budimansyah, 2007: 7).

Group investigation adalah kelompok kecil untuk menuntun dan mendorong taruna dalam keterlibatan belajar. Metode ini menuntut taruna untuk memiliki kemampuan yang baik dalam berkomunikasi maupun dalam keterampilan proses kelompok (group process skills). Hasil akhir dari kelompok adalah sumbangan ide dari tiap anggota serta pembelajaran kelompok yang notabene lebih mengasah kemampuan intelektual taruna dibandingkan belajar secara individual. Setiap kelompok bekerja berdasarkan metode investigasi yang telah mereka rumuskan. Aktifitas tersebut merupakan kegiatan sistemik keilmuan mulai dari mengumpulkan data, sintesis, hingga menarik kesimpulan (Suprijono, 2015:112).

Model Pembelajaran Group Investigation juga terdapat beberapa kekurangannya, yaitu: a) Sedikitnya materi yang tersampaikan pada satu kali pertemuan, b) Sulitnya memberikan penilaian secara personal, c) Tidak semua topik cocok dengan model pembelajaran Group Investigation, model pembelajaran Group Investigation cocok untuk diterapkan pada suatu topik yang menuntut taruna untuk memahami suatu bahasan dari pengalaman yang dialami sendiri, d) Diskusi kelompok biasanya berjalan kurang efektif, e) Taruna yang tidak tuntas memahami materi prasyarat akan mengalami kesulitan saat menggunakan model ini (Lecture, 2012:1).

Penerapan pembelajaran kooperatif tipe group investigation dapat meningkatkan hasil belajar pada materi Writting Aviation Job di Kelas Teknik Listrik Bandara XI B ATKP Surabaya Tahun Ajaran 2016/2017.

\section{Metode Penelitian}

Rancangan penelitian diperlukan dalam penelitian ini, untuk membantu alur pemikiran yang jelas pada jalannya penelitian. Penelitian ini menggunakan penelitian tindakan karena penelitian tindakan kelas adalah merupakan penelitian yang lebih sesuai dengan tugas pokok dan fungsi dosen, meningkatkan kualitas pembelajaran, meningkatkan kualitas taruna, serta mencapai tujuan pembelajaran atau pendidikan.

Penelitian ini dilaksanakan di Kelas Teknik Listrik Bandara XIB ATKP Surabaya, untuk pelajaran Bahasa Inggris pada materi Writting Aviation Job dan dilaksanakan pada bulan Februari 2017. Dalam penelitian ini yang menjadi subyek penelitian adalah taruna 
Teknik Listrik Bandara Kelas XIB ATKP Surabaya Tahun Pelajaran 2016/2017 seluruhnya adalah 24 taruna.

Teknik pengumpulan data pada penelitian ini adalah observasi dan tes. Pemberian tindakan dilakukan melalui dua siklus dan evaluasi dilakukan diakhir siklus untuk mengetahui hasil belajar taruna pada setiap siklus. Tes adalah suatu alat pengumpul informasi, bersifat lebih resmi karena penuh dengan batasan-batasan (Arikunto, 2012:33).

Instrumen penelitian pada penelitian ini adalah lembar observasi dan soal tes. Lembar Observasi digunakan oleh peneliti dan pengamat (teman sejawat). Lembar Observasi dalam penelitian ini adalah lembar observasi untuk pengamatan langsung yaitu peneliti dan pengamat melihat dan mengamati secara langsung kemudian mencatat perilaku dan kejadian yang terjadi pada keadaan yang sebenarnya. Soal ini diberikan pada taruna setiap akhir siklus. Tes dilakukan untuk mengetahui hasil belajar awal taruna sehingga peneliti dapat merencanakan tindakan yang akan diambil dalam memperbaiki proses pembelajaran. Pemberian tindakan dilakukan melalui tiga siklus dan evaluasi dilakukan diakhir siklus untuk mengetahui hasil belajar taruna pada setiap siklus.

Pada tahap ini teknik analisis data yang dipergunakan adalah reduksi data, penyajian data, penarikan simpulan, serta verifikasi refleksi. Penelitian ini dilandasi prinsip kolaboratif dan kooperatif, sehingga penyiapan partisipaan dipandang perlu dilakukan kegiatan awal. Melakukan diskusi dengan teman sejawat dosen Bahasa Inggris tentang desain atau strategi pembelajaran pada materi Writting Aviation Job yang diikuti dengan penyusunan rencana kegiatan.

Refleksi awal dilaksanakan dengan melakukan pengamatan pendahuluan untuk mengetahui kondisi awal dilakukan pengamatan oleh rekan sejawat saat dosen melakukan proses pembelajaran. Hasil analisis refleksi awal digunakan untuk menetapkan dan merumuskan rencana tindakan yaitu menyusun strategi awal pembelajaran. Laporan hasil penelitian ini disajikan sebagai hasil upaya pengolahan data menjadi sesuatu yang dapat diutarakan secara jelas dan tepat dengan tujuan agar dapat dimengerti oleh orang yang tidak langsung mengalaminya sendiri. Deskripsi data diperlukan untuk memberi gambaran pada penelitian ini (Wikipedia, 2015: 1).

Penulisan laporan penelitian ini dilandasi prinsip kolaboratif dan kooperatif, sehingga penyiapan partisipaan dipandang perlu dilakukan kegiatan awal. Melakukan diskusi dengan teman sejawat dosen Bahasa Inggris tentang desain atau strategi pembelajaran pada materi penjumlahan dan pengurangan pecahan yang diikuti dengaan penyusunan rencana kegiatan. 


\section{Hasil Penelitian}

\section{Sebelum Tindakan}

Refleksi awal dilaksanakan dengan melakukan pengamatan pendahuluan untuk mengetahui kondisi awal dilakukan pengamatan oleh rekan sejawat saat dosen melakukan proses pembelajaran. Hasil analisis refleksi awal digunakan untuk menetapkan dan merumuskan rencana tindakan yaitu menyusun strategi awal pembelajaran.

Berdasarkan data pendahuluan ditemukan bahwa selama pembelajaran berlangsung sebagian besar taruna cenderung kurang berminat menyelesaikan soal-soal latihan, dan dosen harus selalu mengingatkan agar taruna mengerjakan latihan, kurang memperhatikan penjelasan dosen, kurang bersemangat dan cenderung pasif, tidak aktif dalam mengemukakan pendapat atau bertanya dalam mengikuti proses pembelajaran.

Minat belajar taruna dalam pembelajaran kurang ditandai dengan banyaknya taruna selama pembelajaran berlangsung tidak ada minat untuk segera menyelesaikan tugas yang diberikan oleh dosen. Minat untuk bertanya juga kurang karena taruna cenderung pasif pada waktu dosen memberikan pertanyaan atau saat dosen memberikan tugas. Selanjutnya dilakukan refleksi atau pemaknaan terhadap perilaku taruna tersebut. Berdasarkan hasil refleksi dapat disimpulkan bahwa taruna kurang berminat dan kurang terampil dalam belajar Writting Aviation Job. Karena belum sesuai standar ketuntasan maka perlu dilakukan tndakan siklus pertama dengan melakukan tahapan perencanaan, tindakan, observasi, dan refleksi. Hasil wawancara dengan dosen dapat diketahui bahwa taruna dalam pembelajaran sebelum tindakan memiliki hasil belajar taruna rata-rata 75,42 , yang tuntas ada 14 taruna $(58,33 \%)$ yang tidak tuntas ada 10 taruna $(41,67 \%)$.

Hasil Belajar Sebelum Tindakan

\begin{tabular}{|c|c|c|}
\hline No & Nama & Nilai \\
\hline 1 & & 80 \\
\hline 2 & & 80 \\
\hline 3 & & 80 \\
\hline 4 & & 70 \\
\hline 5 & & $\overline{70}$ \\
\hline 6 & & 80 \\
\hline 7 & & 70 \\
\hline 8 & & 80 \\
\hline
\end{tabular}

\begin{tabular}{|c|c|c|}
\hline No & Nama & Nilai \\
\hline 9 & & 80 \\
\hline 10 & & 70 \\
\hline 11 & & 70 \\
\hline 12 & & 70 \\
\hline 13 & & 80 \\
\hline 14 & & 80 \\
\hline 15 & & 60 \\
\hline 16 & & 80 \\
\hline
\end{tabular}

\begin{tabular}{|c|c|c|}
\hline No & Nama & Nilai \\
\hline 17 & & 80 \\
\hline 18 & & 80 \\
\hline 19 & & 70 \\
\hline 20 & & 80 \\
\hline 21 & & 90 \\
\hline 22 & & 80 \\
\hline 23 & & 70 \\
\hline 24 & & 60 \\
\hline
\end{tabular}

\section{Siklus Pertama}




\section{a. Perencanaan}

Melakukan pertemuan dengan teman sejawat selaku pengamat untuk membicarakan persiapan kegiatan pembelajaran dengan pemberian pretes yang dilakukan pada saat penelitian. Mendiskusikan dan menetapkan rancangan pembelajaran yang akan diterapkan di kelas sebagai tindakan. Mempersiapkan alat dan bahan yang diperlukan untuk melaksanakan penelitian. Mempersiapkan waktu dan cara pelaksanaan diskusi hasil pengamatan dengan praktisi dan wawancara dengan subyek. Mempersiapkan buku perekam data. Menyusun rencana pembelajaran. Mempersiapkan perangkat tes hasil belajar pada siklus pertama. Mengelompokkan taruna secara heterogen.

\section{b. Pelaksanaan Tindakan}

Melaksanakan kegiatan pembelajaran berpedoman pada RPS yang telah dibuat yang telah disesuaikan berdasarkan kerangka berfikir. Melakukan penilaian menggunakan alat penilaian yang telah disediakan.

\section{c. Observasi}

Observasi dilakukan oleh teman sejawat sebagai mitra kolaborator. Kolaborator mencatat semua aktivitas yang dilakukan oleh dosen dan taruna selama proses pembelajaran, yaitu mulai kegiatan awal hingga kegiatan akhir. Observasi dilakukan dengan instrumen observasi.

\section{d. Refleksi}

Catatan di lapangan dan jurnal harian sebagai hasil pengamatan maupun hasil wawancara dikaji dan direnungkan kembali. Data yang terkumpul dikaji secara komprehensif. Data dibahas bersama pengamat untuk mendapat kesamaan pandangan terhadap tindakan pada siklus pertama. Hasil refleksi dijadikan bahan untuk merevisi rencana tindakan selanjutnya.

\begin{tabular}{|c|c|c|}
\hline No & Nama & Nilai \\
\hline 1 & & 90 \\
\hline 2 & & 80 \\
\hline 3 & & 80 \\
\hline 4 & & 90 \\
\hline 5 & & 70 \\
\hline 6 & & 80 \\
\hline 7 & & 90 \\
\hline 8 & & 80 \\
\hline
\end{tabular}

Hasil Belajar Siklus Pertama

\begin{tabular}{|c|c|c|c|c|c|}
\hline No & Nama & Nilai & No & Nama & Nilai \\
\hline 9 & & 90 & 17 & & 80 \\
\hline$\overline{10}$ & & 70 & 18 & & 80 \\
\hline 11 & & 80 & 19 & & 70 \\
\hline 12 & & 70 & 20 & & 90 \\
\hline 13 & & 80 & 21 & & 90 \\
\hline 14 & & 80 & 22 & & 80 \\
\hline 15 & & 90 & 23 & & 80 \\
\hline \multirow[t]{2}{*}{16} & & 80 & 24 & & 70 \\
\hline & & & & & 80.83 \\
\hline
\end{tabular}


Berdasarkan pengamatan, taruna dalam pembelajaran pada siklus pertama hasil belajar taruna rata-rata 80,83, yang tuntas ada 19 taruna $(79,17 \%)$ yang tidak tuntas ada 5 taruna (20,83\%). Pada siklus pertama memanfaatkan gambar-gambar Writting Aviation Job. Karena belum sesuai standar ketuntasan dilanjutkan pada siklus kedua.

\section{Siklus Kedua}

\section{a. Perencanaan}

Melakukan pertemuan dengan teman sejawat selaku pengamat untuk membicarakan persiapan kegiatan pembelajaran dengan pemberian pretes yang dilakukan pada saat penulisan laporan penelitian. Mendiskusikan dan menetapkan rancangan pembelajaran yang akan diterapkan di kelas sebagai tindakan penulisan laporan penelitian. Mempersiapkan penulisan laporan penelitian dan bahan yang diperlukan untuk melaksanakan penulisan laporan penelitian. Mempersiapkan waktu dan cara pelaksanaan diskusi hasil pengamatan dengan praktisi dan wawancara dengan subyek penulisan laporan penelitian. Mempersiapkan buku perekam data. Menyusun rencana pembelajaran. Mempersiapkan perangkat tes hasil belajar pada siklus pertama. Mengelompokkan taruna secara heterogen.

\section{b. Pelaksanaan Tindakan}

Melaksanakan kegiatan pembelajaran berpedoman pada RPS yang telah dibuat yang telah disesuaikan berdasarkan kerangka berfikir. Melakukan penilaian menggunakan alat penilaian yang telah disediakan.

\section{c. Observasi}

Observasi dilakukan oleh teman sejawat sebagai mitra kolaborator. Kolaborator mencatat semua aktivitas yang dilakukan oleh dosen dan taruna selama proses pembelajaran, yaitu mulai kegiatan awal hingga kegiatan akhir. Observasi dilakukan dengan instrumen observasi.

\begin{tabular}{|c|c|c|}
\hline No & Nama & Nilai \\
\hline 1 & & 100 \\
\hline 2 & & 80 \\
\hline 3 & & 90 \\
\hline 4 & & 90 \\
\hline 5 & & 80 \\
\hline 6 & & 80 \\
\hline 7 & & 90 \\
\hline 8 & & 90 \\
\hline
\end{tabular}

Hasil Belajar Siklus Kedua

\begin{tabular}{|c|c|c|}
\hline No & Nama & Nilai \\
\hline 9 & & 90 \\
\hline 10 & & 80 \\
\hline 11 & & 80 \\
\hline 12 & & 80 \\
\hline 13 & & 80 \\
\hline 14 & & 90 \\
\hline 15 & & 90 \\
\hline 16 & & 90 \\
\hline
\end{tabular}

\begin{tabular}{|c|c|c|}
\hline No & Nama & Nilai \\
\hline 17 & & 80 \\
\hline 18 & & 80 \\
\hline 19 & & 80 \\
\hline 20 & & 90 \\
\hline 21 & & 90 \\
\hline 22 & & 90 \\
\hline 23 & & 80 \\
\hline 24 & & 80 \\
\hline
\end{tabular}


Pada siklus kedua ini taruna lebih aktif dalam potensi Writting Aviation Job. Berdasarkan pengamatan, taruna dalam pembelajaran pada siklus kedua hasil belajar taruna rata-rata 85,42 dan pada siklus kedua yang tuntas ada 24 taruna (100\%). Siklus kedua lebih berhasil karena saat pembelajaran dengan group investigation memanfaatkan youtube.

Model Group Investigation ini dapat melatih kreativitas siwa, baik secara perorangan maupun kelompok dalam menulis berita serta melatih kemampuan taruna dalam bertanggung jawab dalam menyelesaikan suatu masalah. Model ini mengajak taruna untuk aktif dan kreatif menulis berita atau peristiwa yang terjadi di sekitarnya. Dengan demikian, kreativitas taruna dalam menulis akan bertambah.

\section{Kesimpulan dan Saran}

Kesimpulan pada penelitian tidakan kelas ini: 1) Hasil penelitian dapat disimpulkan bahwa taruna dalam pembelajaran sebelum tindakan memiliki hasil belajar taruna rata-rata 75,42, yang tuntas ada 14 taruna (58,33\%) yang tidak tuntas ada 10 taruna (41,67\%). 2) Berdasarkan hasil penelitian, taruna dalam pembelajaran siklus pertama hasil belajar taruna rata-rata 80,83, yang tuntas ada 19 taruna $(79,17 \%)$ yang tidak tuntas ada 5 taruna (20,83\%). Pada siklus pertama memanfaatkan gambar-gambar Writting Aviation Job. 3) Pada siklus kedua ini taruna lebih aktif dalam potensi Writting Aviation Job. Berdasarkan pengamatan, taruna dalam pembelajaran pada siklus kedua hasil belajar taruna rata-rata 85,42 dan pada siklus kedua yang tuntas ada 24 taruna (100\%). Siklus kedua lebih berhasil karena saat pembelajaran dengan group investigation memanfaatkan youtube.

Dari hasil penelitian, dapat disarankan: dosen dapat mempergunakan metode pembelajaran yang sesuai untuk tiap materi pembelajaran, dosen dapat meningkatkan motivasi belajar taruna dengan mempergunakan metode pembelajaran yang sesuai yang pada akhirnya akan meningkatkan prestasi belajar taruna. Manajemen ATKP Surabaya dapat meningkatkan kualitas dan profesionalisme dosen melalui pelatihan metode pembelajaran. Pengelola ATKP Surabaya dapat memfasilitasi dosen untuk mengikuti pelatihan metode pembelajaran untuk meningkatkan kinerja dosen. Peneliti lain dapat mempergunakan hasil penelitian ini untuk mengembangkan penelitian ini. Peneliti lain dapat mempergunakan hasil penelitian ini sebagai data untuk penelitian lanjutan. 


\section{DAFTAR PUSTAKA}

Arikunto, Suharsimi. 2009. Dasar-Dasar Evaluasi Pendidikan. Jakarta:Bumi Aksara.

Budimansyah. 2007. Belajar Kooperatif Model Penyelidikan Kelompok dalam Pembelajaran Membaca Pemahaman untuk Meningkatkan Keterampilan Membaca Taruna Kelas V SD. Tesis tidak diterbitkan. Malang: Program studi pendidikan Bahasa dan Sastra SD, Pascasarjana Universitas Negeri Malang

Sagala, Syaiful. 2008. Konsep dan Makna Pembelajaran. Bandung: Alfabeta Suprijono, Agus. 2015. Cooperative Learning. Yogyakarta: Pustaka Pelajar

Suprijono, Agus. 2016. Model-Model Pembelajaran Emansipatoris. Yogyakarta: Pustaka Pelajar

Trianto. 2011. Model-Model Pembelajaran Inovatif Berorientasi Konstruktivistik. Jakarta: Prestasi Pustaka 